\title{
Magnetic resonance imaging of cerebellar schistosomiasis mansoni
}

\author{
Ressonância magnética na esquistossomose mansoni cerebelar
}

\section{Bruno Perocco Braga1, Leodante Batista da Costa Junior ${ }^{1}$ and José Roberto Lambertucci ${ }^{2}$}



A



B

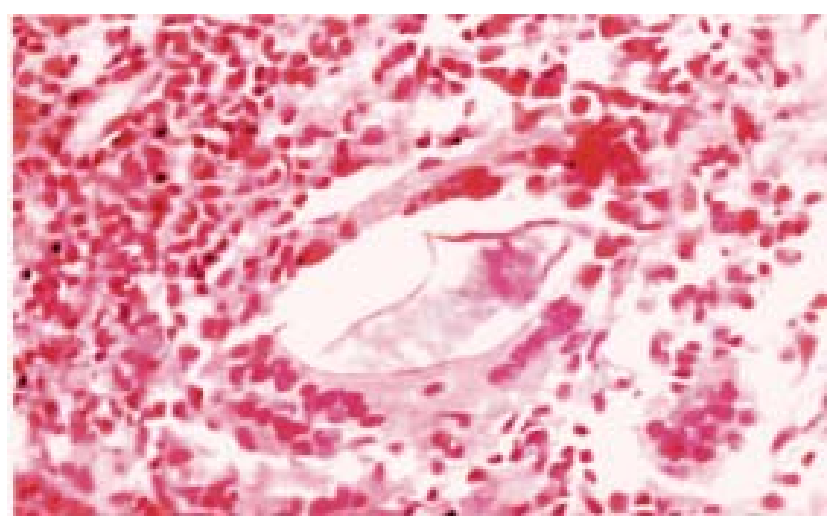

C

1. Serviço de Neurocirurgia do Hospital da Baleia, Belo Horizonte, MG. 2. Serviço de Doenças Infecciosas e Parasitárias da Faculdade de Medicina da Universidade Federal de Minas Gerais, Belo Horizonte, MG.

Address to: Dr Bruno Perocco Braga. Rua Professor Antonio Aleixo 300/1703, 30180-150 Belo Horizonte, MG

e-mail: bpbraga@ terra.com.br

Recebido para publicação em 30/6/2003

Aceito em 23/7/2003 
A 15-year-old boy was admitted to hospital with a history of headache, dizziness, vomiting and double vision that started two weeks before. His parents denied any previous disease. During clinical examination he presented diplopia on lateral gaze to the left and horizontal nystagmus. No major neurological dysfunction was detected. He was well built, mentally responsive and perceptive. Laboratory findings revealed a leukocyte count of $10,000 / \mu \mathrm{L}$, a normal red blood cell count and no eosinophilia. The magnetic resonance images (MRI) of the brain showed a left cerebellar lesion with mass effect compressing the surrounding tissues. Contrast-enhanced images showed a mass like structure and punctate nodules (Figures A and B: axial and coronal contrast-enhanced T1-weighted MR images showed the nodular - yellow arrows - enhancement pattern of a left cerebellar intraxial lesion). The lesion extended to the vermis and brachium pons and compressed the medulla. There was no hydrocephalus. He was taken to the operating room with the presumptive diagnosis of a neuroglial tumor, and submitted to a lateral suboccipital craniectomy. A brown, brittle tumoral mass without a clearly defined margin with the cerebellar tissue was removed. Microscopic examination revealed schistosomal granulomas in the productive phase in the cerebellum (Figure C). After surgery, treatment with praziquantel (50mg/kg/dia, single dose) and prednisone $(1 \mathrm{mg} / \mathrm{kg} /$ day) was offered and the patient improved quickly. Thirty days later he was seen again at the outpatient clinic: he was asymptomatic and with no neurological impairment. This is the eighth case of cerebellar involvement in schistosomiasis mansoni and the second report of a tumoral form of cerebellar schistosomiasis documented by magnetic resonance images.
O paciente, de 15 anos de idade, previamente hígido, foi admitido ao Hospital da Baleia em Belo Horizonte, com história de cefaléia universal, tonteira, vômitos e visão dupla iniciados há duas semanas. Ao exame clínico, observou-se diplopia na mirada lateral para a esquerda e nistagmo horizontal, sem outros déficits neurológicos. O paciente apresentava bom aspecto geral e desempenho intelectual esperado para a idade. Os exames de laboratório não revelaram alterações: os leucócitos globais eram de 10.000/ $\mathrm{LL}$, com contagem normal de eritrócitos e sem eosinofilia. A ressonância magnética do cérebro mostrou a presença de lesão no hemisfério cerebelar esquerdo, com efeito de massa, e captação granular de gadolínio em pontos (Figuras $A$ e $B$ : ressonância nuclear magnética em corte axial e coronal em T1, com contraste, onde observa-se lesão cerebelar esquerda com o aspecto de nódulos múltiplos - setas amarelas). A lesão estendia-se ao lobo médio e atingia o braço direito da ponte, com alguma compressão do tronco cerebral. Não se nota hidrocefalia. O paciente foi encaminhado para tratamento neurocirúrgico com a hipótese diagnóstica de tumor de origem glial. Realizouse, então, craniectomia suboccipital esquerda e removeuse uma massa tumoral pardacenta, friável, sem limites definidos. O exame histológico do material revelou a presença de vários granulomas esquistossomóticos na fase produtiva no tecido cerebelar (Figura C). O paciente recebeu praziquantel (50mg/kg/dia, em dose única) e prednisona ( $1 \mathrm{mg} / \mathrm{kg} / \mathrm{dia})$, e evoluiu com melhora rápida do quadro clínico. Trinta dias após a alta hospitalar, ele foi examinado em ambulatório: encontrava-se assintomático e sem déficits neurológicos. Este é o oitavo caso de esquistossomose cerebelar descrito na literatura e o segundo caso documentado pela ressonância magnética do cérebro.

\section{REFERENCES}

1. Ferreira LA, Lima FFC, Anjos MRO, Costa JML. Forma tumoral encefálica esquistossomótica: apresentação de um caso tratado cirurgicamente. Revista da Sociedade Brasileira de Medicina Tropical 31: 89-93, 1998.

2. Pittela JEH, Gusmão SNS, Carvalho GTC, Silveira RL, Campos GF. Tumoral form of cerebral schistosomiasis mansoni. A report of four cases and a review of the literature. Clinical Neurology and Neurosurgery 98: 15-20, 1996.

3. Sanelli PC, Lev MH, Gonzalez RG, Schaefer PW. Unique linear and nodular MR enhancement pattern in schistosomiasis of the central nervous system: report of three patients. American Journal of Radiology 177: 1471-1474, 2001. 